\title{
PATRIMONIO Y PROPAGANDA DE GUERRA
}

\author{
LUIS BEN ANDRÉS \\ Director de Vigía ObServatorio de la provincia \\ DE CÁDIZ
}

\section{RESUMEN}

Tras un breve comentario acerca de las circunstancias en que fue encontrado el opúsculo del prof. Kohlhausen, se pasa a su reproducción íntegra en la que se hace relación, país por país, de las condiciones y juicio de valor en que se encontraba el patrimonio artístico y monumental de los distintos territorios europeos ocupados por el ejército alemán durante la Segunda Guerra Mundial así como de las medidas y actuaciones tomadas para su salvaguardia e integridad.

Palabras claves: Patrimonio Artístico y Monumental, países europeos, ejército alemán, Segunda Guerra Mundial.

\section{ABSTRACT}

After a brief commentary about the circumstances in that the opuscule of Prof. Kohlhausen was found, one goes to his complete reproduction in whom relation becomes, country by country, of the conditions and judgment of value in which the artistic and monumental patrimony of the different European territories occupied by the German army during World War II as well as of the measures was and performances taken for its safeguard and integrity.

Key words: Artistic and Monumental patrimony, European countries, German army, World War II.

La casualidad no debe ser un elemento esencial en la investigación histórica, sin embargo a veces es el detonante que despierta la curiosidad del investigador o le dirige hacia una nueva línea de trabajo. Éste es el caso que comentaré. La ciudad de Cádiz era sede de uno de los consulados de la República Argentina en España. En el año 1997 fue suprimido por el gobierno de dicha nación. El consulado compartía sede con la Fundación Provincial de Cultura de la Diputación de Cádiz y en los trabajos de mudanza el personal del consulado procedía desechar numerosos muebles y papeles que consideraban inútiles o 
prescindibles. Entre estos recuperé un opúsculo de 34 páginas, más tarde descubrí que había sido cortada una hoja, titulado "La labor del Servicio Alemán de Protección Artística en pro de la conservación de los valores culturales europeos (medidas contra el terror aéreo anglosajón)" ". Escrito en castellano figuraba como autor el Profesor Doctor H. Kohlhausen (sic). Impreso a una sola tinta y con unas medidas de 20,50 por $14,50 \mathrm{~cm}$., sus veinte primeras páginas correspondían al texto corrido y el resto a láminas de fotografías en las que se ilustraba el tema sobre el que trata.

Aunque las personas bienintencionadas crean lo contrario, la guerra suele ser el estado más frecuente en las sociedades. En todo momento, en algún lugar del planeta, con diferente intensidad, la guerra es un fenómeno presente. La guerra es un hecho histórico y escuelas tradicionales han hecho de ella el centro de sus estudios. Nada de lo humano le es ajeno, la Historia tampoco. Ante esta realidad, algo tan delicada como es el patrimonio histórico o cultural, es altamente sensible. Ejemplos sobran desde la antigüedad al mundo más contemporáneo. Cuando los pueblos, las naciones, los ejércitos se enfrentan, tan importante como las propias acciones de combate resulta la labor de propaganda. No nos referimos en el caso que nos ocupa a la mera propaganda que se dirige a desmoralizar tanto a la tropa como a la retaguardia que la sostiene. Estamos ante algo más complejo, como el ámbito al que se enfoca, el patrimonial.

Sobre el autor aun no poseo demasiados datos pero sí los suficientes para una primera aproximación. Heinrich Kohlhausen (1894-1970) era historiador del arte y fue director del Museo Nacional Alemán de Nuremberg en el período de la II Guerra Mundial incluso desde antes, 1936. Destacó por su labor tanto en la gestión del museo desde un punto de vista científico, como en su esfuerzo por preservarlo de la acción de la guerra. Parece ser que no fue un hombre afecto al nacionalsocialismo, quizás estuviera en una actitud más bien tibia o no comprometida en ningún sentido. Hemos podido localizar el título de dos obras suyas: La orfebrería en Nurembreg de la Edad Media a la Moderna, 1240 a 1540 y La Historia de la artesanía alemana, ésta última fechada en Munich en 1955. En 1945 fue nombrado director de la colección de arte de Veste Coburg (Baviera) a cuyo frente permaneció hasta el año 1959, por lo que es de suponer que no estuvo sometido al proceso de desnazificación o simplemente que fue rápidamente asimilado para la reconstrucción del país. De la lectura del libro se desprende más una indignación derivada de la brutalidad en los ataques aéreos de los aliados que de una posición ideológica pronazi de salida.

En la obra, escrita en un buen castellano que nos hace pensar en una traducción cuidada, se dedica más espacio a la descripción de los trabajos del Servicio Alemán de Protección Artística que a la recriminación al enemigo. Tras una breve introducción, en la que se elabora una curiosa teoría para explicar el desprecio de ingleses y norteamericanos hacia el patrimonio cultural y que el autor fundamenta en motivos de carácter y psicología de los anglosajones, la obra es prolija en describirnos los trabajos realizados tanto en Alemania como en los "países vencidos" (sic). Se incide de una parte en las llamadas medidas protectoras, salvaguarda de monumentos, traslados de patrimonio mueble, etc. Destaca, por la envergadura del esfuerzo, la fotografía (10.000) y catalogación de las vidrieras de catedrales e iglesias. Los archivos y bibliotecas también tienen su tratamiento específico para el servicio. Resulta curiosa la descripción de los trabajos fuera de Alemania, en concreto en Francia, Bélgica, Italia, Serbia y Grecia. La valoración es muy diferente, en lo que respecta a los sistemas locales de protección del patrimonio, según que países. Así te- 
nemos una valoración muy positiva del caso francés a una recriminación áspera para con las autoridades griegas.

En lo referente a la organización del servicio, éste dependía totalmente de las autoridades militares alemanas de ocupación en cada territorio. La supeditación a la esfera militar era total aunque el autor trata de ofrecer ejemplos de buena colaboración y actitud de la misma. En esta línea resalta el traslado de la biblioteca y archivos del monasterio de Monte Cassino al Vaticano por la División Hermamm Góring. El folleto ofrece aspectos muy diversos que permitirían iniciar distintas e interesantes líneas de investigación, desde las más genéricas sobre Patrimonio y conflictos bélicos, hasta otras más concretas sobre el impacto de la II Guerra Mundial en distintos países.

La labor del Servicio Alemán de Protección Artística en pro de la conservación de los valores culturales europeos.

(Medidas contra el terror aéreo anglosajón)

POR EL Profesor Doctor H. KOHLHÁUSEN

1944

ARTEM non odit nisi ignarus: "Sólo el bárbaro odia el arte". Como un fanal resplandece esta inscripción sobre el frontispicio semicalcinado del Nuevo Museo de Berlín, a modo de advertencia para Europa y de anatema para los criminales. Lo que hoy presenciamos con dolor y escalofríos de espanto es, en efecto, sea cualesquiera la actitud que frente a ello se adopte, un crimen contra Europa y un atentado contra su cultura.

En épocas anteriores se causaron, también, no hay duda, daños inmensos en los monumentos culturales, y guerras, iconoclastas, incomprensión e indiferencia provocaron lagunas terribles en este sector. ¿Cuándo, empero, se ha arrasado una cultura tan sistemática mente como en a actualidad? Para poder responder a esta pregunta habríamos de examinar uno por uno los diversos países. Lo mayoría de las guerras han tenido lugar sobre el suelo de Alemania, el país nuclear de Europa, y sólo la Guerra de los Treinta Años paralizó la nación durante decenios, devastando ciudades y aldeas, mientras que antes y después de ella ejércitos extranjeros azotaron O tierra alemana, en especial los franceses de Luís XIV, a finales el siglo XVII. No obstante, el número de monumentos culturales de origen alemán que conservaba el Reich a comienzos de la guerra actual superaba al de los países vecinos. ¿Cómo explicar este hecho? Francia ha sufrido dos grandes sangrías: una en las postrimerías de la Edad Media, a causa de la Guerra de los Cien Años con Inglaterra, durante la cual los ingleses mantuvieron ocupados grandes sectores del territorio francés, y otra, la mayor, en el curso de la Revolución francesa, durante los últimos años del siglo XVIII.

Inglaterra, en cambio, puede decirse que no ha tenido jamás ningún enemigo extranjero en su propio territorio desde que se constituyó como nación en la alta Edad Media. $Y$, sin embargo, es Inglaterra el país europeo más pobre en riquezas artísticas, y en los testimonios de su cultura antigua se echan de ver lagunas que abarcan, a veces, siglos enteros. Los tesoros deslumbrantes de los museos londinenses, que atraían antes de esta guerra el interés del visitan son, en su mayor parte, de procedencia extranjera: botín traído de Grecia y Egipto y adquisiciones hechas en Italia, Alemania y Francia. Además del movimiento iconoclasta de la Reforma, Inglaterra experimentó durante a revolución puritano del siglo XVII otro de efectos incomparablemente más devastadores. Este segundo movimiento 
no fue tan sólo una erupción repentina de fanatismo religioso, sino una campaña de destrucción artística realizada sistemáticamente durante años enteros.

Ahora nos percatamos de que la estúpida acción sistemática de destrucción por el fuego del núcleo histórico de as antiguas y magníficas ciudades del continente, de que el incendio intencionado de catedrales y castillos, residencias y aldeas, y de que esa carencia absoluta de respeto ante los santuarios nacionales o ante aquellos monumentos que son patrimonio de la Humanidad entera, es algo que se acornada perfectamente al carácter de los anglosajones.

Lo que un día fue grande en el suelo inglés, grande, en parte también, por los influjos vivificadores venidos del continente, que durante siglos enteros dieron impulso y sirvieron de ejemplo al arte insular, todo ello tuvo que desaparecer y hundirse ante la arrogante intolerancia, ante la estrechez de horizontes y la soberbia farisaica del puritano.

Lo mismo ocurre hoy. Las naciones europeas defienden y protegen con su sangre sus más sagrados monumentos. Los anglosajones, en cambio, los deshacen con un cálculo frío y despiadado. Lo que escapa a ésta destrucción es subastado al mejor postor, e incluso partes aisladas de monumentos arquitectónicos, como, por ejemplo, la portada de la catedral de Monreale, cerca de Palermo (Sicilia), son desmontadas para volver a ser reconstruidas, en absurdo aislamiento, en alguna finca particular de Norteamérica.

En el curso de uno conversación mantenida, hace ahora quince años, refutaba yo la opinión de un compañero que sostenía que toda obra de arte, un Durero, por ejemplo, tenía que ejercer en los Estados Unidos un determinado influjo como mensajera y paladín de la cultura alemana. El hombre sin cultura es totalmente insensible al influjo sublime de las grandes obras de arte. Antes, al contrario, éstas provocan su cólera y su odio, porque no puede oponerlas nada parecido en su país, a no ser las grandes realizaciones técnicas, en las cuales la "grandiosidad" está en el tamaño y e la masa.

Quien quisiera realizar un inventario de los daños causados durante la guerra actual en los monumentos culturales europeos, se vería ante un cometido tan doloroso como imposible. Cada día, en efecto, se hace mayor la destrucción y cada día penetran nuevas regiones pacíficas en el ámbito de la devastación. Unas veces es la catedral de Estrasburgo, considerada horas antes como un símbolo inviolable de la cultura europea, la que desaparece, y otras los tesoros arquitectónicos de Tréveris los que quedan convertidos en cenizas. Lo enumeración de las pérdidas sufridas por Europa en el sector cultural se identifico, poco más o menos, con los daños padecidos por todo aquello que, desde la antigüedad, sostenía el ritmo grandioso de a historia cultural europea. Escojamos, en efecto, uno u otro aspecto de este sector: por doquiera nos encontraremos con lagunas dolorosas y con heridas incurables. Algunas preguntas nos pondrán esto más claramente de manifiesto. ¿En qué estado se encuentran los lugares en que eran nombrados y con sagrados os emperadores y reyes alemanes? Destrozados, consumidas por las llamas, se encuentran el Römer y el Kaiserdom, en Francfort del Meno; las Casas Consistoriales y la catedral de Aquisgrán, las Casas Consistoriales de Augsburgo, obra de Elías Holl, y célebres tanto por las reuniones en ellas celebradas como por su belleza arquitectónica; alcanzado por las bombas el antiguo palacio imperial de Nuremberg, y víctima en gran parte del fuego la antiquísima parte vieja de Maguncia.

¿En qué estado se encuentran las residencias de los Hohenzollern en Chalottenburg y Berlín, y de los Wittelsbacher en Munich, palacio fastuoso con doscientos aposentos, que durante cinco siglos ha sido testimonio vivo del refinamiento doméstico de una Casa rei- 


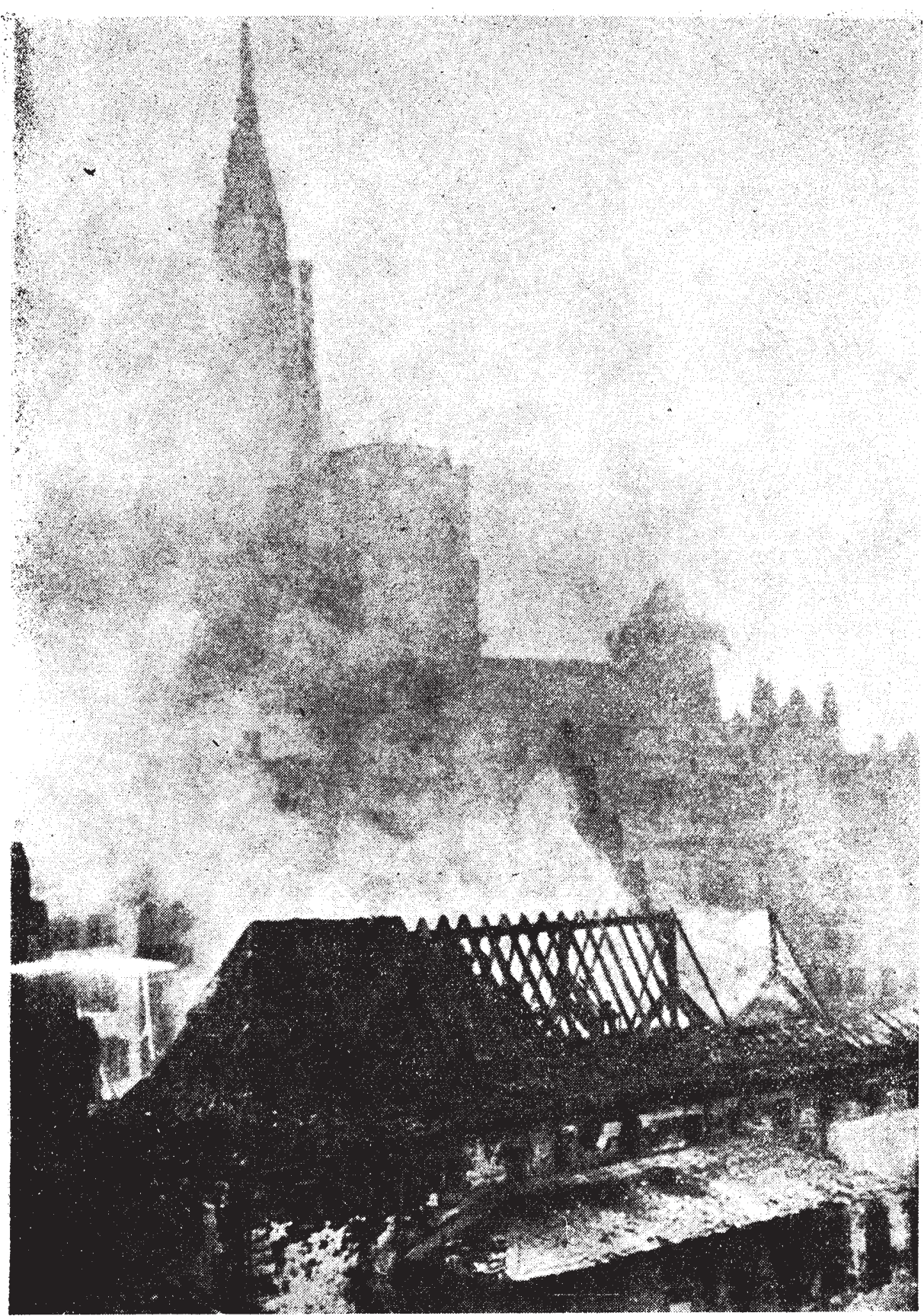

La parte vieja de Estrasburgo envuelta en llamas después del ataque aéreo del 11 de agosto de 1944. En el curso de este ataque fué destruida la torre del crucero de la catedra! 
nante? ¿Qué ha sido de los palacios de Stuttgart, Mannheim, Kassel y Hannover? ¿Qué de todos aquellos lugares tan amados, llenos de recuerdos goethianos? Nunca más volverá a poder entregar la Casa de Sakespeare la tradicional corona destinada al cuarto donde naciera Goethe en la casa del Hirsch graben, en Francfort, pues el cuarto, la casa y la calle entera han sido destruidos; y, a la vez, a casa de Lili Schönemann, a amiga del poeta, en el Kornmarkt; la de su tía Melber, en el Hühnermarkt; la deliciosa casita de Marianne von Willemer, en el Sachsenhausberg, e incluso a tumba de la madre del poeta. ¿Y en qué estado se halla la casa que habitó Goethe durante su estancia, como estudiante, en Estrasburgo? ¿Han quedado a salvo de las bombas enemigas los lugares goethianos esparcidos por Weimar, Wetzlar y Jena?

$Y$ si dirigimos la vista a Italia, tan visitada por el dolor, iqué proporciones no adquieren las devastaciones a partir de Salerno, pasando por Agnani, Viterbo, Perugia, Pisa, Arezzo, de Génova a Florencia, Bolonia, Turín, Milán y tantos y tantos otros lugares rebosantes de historia y de arte! ¿Qué ha sido de Tívoli, lugar de cita durante años enteros de artistas alemanes, franceses e italianos, cuya cascada, con su antiguo templo, es, sin duda, el paisaje más pintado y dibujado del continente? ¿Qué necesidad bélica forzó a los norteamericanos a destruir el monasterio más venerable de Occidente, Monte Cassino, cuna del monacato europeo y lugar conocido de todo el mundo culto desde la clásica descripción de Gregorovius? ¿Cómo pudo convertirse la iglesia de San Marcos, en Venecia, en objetivo de las bombas? ¿Por qué tenían que ser destrozados los celebérrimos frescos de Andrea Mantegna en Padua y por qué había de quedar reducida a escombros, con el mausoleo de Gala Placidia, toda la histórica Ravena?

¿Y qué decir de Francia, cuya "liberación” prepararon durante meses enteros los anglosajones con "tapices de bombas y "campanas de fuego"? Iglesias, palacios, ciudades y aldeas reducidas a cenizas en Normandía, en Bretaña y en la región del Sena, en el Sur y en el Este; aquí y allá, por doquiera, destrucciones horrendas de monumentos y obras culturales. Cuando, en 1940, durante el avance alemán, amenazó el fuego con destruir la catedral de Ruán, el actual Mariscal de Campo von Kluge hizo que soldados de Ingenieros volaran toda una serie de edificios en llamas, lo que hicieron soldados del Reich hubo de hacerse bajo el fuego directo del enemigo. La catedral, entonces salvada, ha sido recientemente una víctima más de las bombas anglosajonas.

Este contraste hace que nuestra atención se centre en el Servicio Alemán de Protección Artística y en la labor por él realizada en el curso de esta guerra. Cuando estalló la contienda, a finales del verano de 1939, los directores de museos y los conservadores de arte de toda Alemania se vieron obligados a renunciar a una labor de noble emulación en la exposición y conservación de los tesoros confiados a su custodia. El papel rector de Alemania en este terreno fue subrayado en el Congreso de la Asociación Internacional de Museos, celebrado en el verano de 1936, y quedó confirmado plásticamente en el curso de la Exposición Universal de París de 1937. En ningún país del mundo se presentó, en formas más variadas y con mayor eco, una herencia tan rica del pasado. Desde los más importantes museos hasta las fundaciones más insignificantes en todos los distritos alemanes reinaba por doquiera el anhelo de ofrecer al visitarte en forma digna y adecuada los tesoros legados por la tradición.

Hizo falta que el terror aéreo se intensificara gradualmente para poner término a esta labor cultural con tal pasión realizada. Mientras que, al principio, bastó con tomar las precauciones necesarias contra posibles incendios y con poner en lugar seguro las obras más 
valiosas, la intensificación de los efectos destructores de las bombas obligó a tomar nuevas y más eficaces medidas preventivas.

Los tesoros culturales que habían de permanecer en el lugar en que se encontraban, especialmente los que formaban parte inseparable de un edificio, los difíciles de transportar o aquéllos no transportables por su fragilidad, fueron protegidos por medio de muros y revestimientos. No obstante, la brutalidad de los ataques repetidos una y otra vez ha causado también entre estos tesoros daños incalculables. ;Cuántas iglesias no han quedado reducidas a cenizas, con toda la esplendente magnificencia de sus altares góticos y barrocos, con lápidas y epitafios gigantescos de las más diversas materias que cubrían par enteras, con pinturas y labrados murales, con sillerías de coro talladas o incrustadas! El con tenido de otros templos quedó deshecho por efecto de 'bombas explosivas, y la sillería del coro de San Gereón, en Colonia, de estilo gótico primitivo, con las deliciosas figuras de San Gereón y Santa Elena, se eleva hoy como una voz acusadora contra esta destrucción desenfrenada.

La repetición despiadada de los ataques y su concentración progresiva han hecho saltar también muchas bóvedas protectoras, construidas a costa de trabajos y esfuerzos sin cuento. Torrentes de fuego penetraron después en su interior, reduciendo así a cenizas obras insustituibles de arte y tantos y tantos tesoros que se había pretendido poner a salvo sacándolos de los museos. Con los palacios de Stuttgart desaparecieron obras verdaderamente únicas del mobiliario medieval, entre ellas, por ejemplo, el célebre banco románico de madera de Alpirsbach, de cuya especie hacía largo tiempo ya que no había ningún ejemplar en los demás países de Europa.

Las obras de arte transportables fueron evacuadas oportunamente de las ciudades y regiones amenazadas, labor que fue en aumento a medida que los ataques eran dirigidos indistintamente contra una u otra región.

No hace falta subrayar que ha sido preciso realizar esfuerzos extraordinarios para encontrar refugios adecuados y para acondicionar éstos convenientemente, dada la amplitud de algunas colecciones. Y ello tanto más cuanto que, a medida que se prolongaba la guerra, se iba haciendo notar lógicamente mayor escasez de lugares que pudieran servir de refugios y más dificultades en los medios de transporte, en el personal y en los materiales de construcción, lo que ha obligado a idear nuevos recursos y procedimientos. Esta labor se multiplicó donde los refugios cayeron también dentro del ámbito de los bombardeos o donde la delicadeza de los tesoros artísticos salvados obligaba a reagruparlas bajo un nuevo criterio. De todo ello surgió una nueva ordenación en la forma de tratar y sistematizar las obras culturales, que, en muchos respectos, se halla en oposición diametral con la ordenación de los tiempos de paz. A medida, en efecto, que lo que, al principio, había sido reunido tenía que ser separado y repartido en diversos lugares, más tenían que esforzarse los custodios de tanta riqueza en no perder las conexiones entre las diversas obras. En todos estos trabajos ha ocupada un lugar de importancia singular la fotografía, y, con ella, el inventario científico y la confección de listas de existencias.

Un grupo del tesoro cultural alemán, los archivos y las bibliotecas, causaba preocupaciones urgentes por su amplitud y por el carácter fácilmente combustible de sus fondos. A ello se debe que, sobre todo en los últimos años, haya sufrido Alemania pérdidas gravísimas en bibliotecas regionales y museos. A la cabeza de toda una serie de bibliotecas de mayor o menor importancia figura, totalmente destruida, la biblioteca del antiguo principado de Hessen, en Kassel, con su sección de obras primitivas de la literatura de to- 


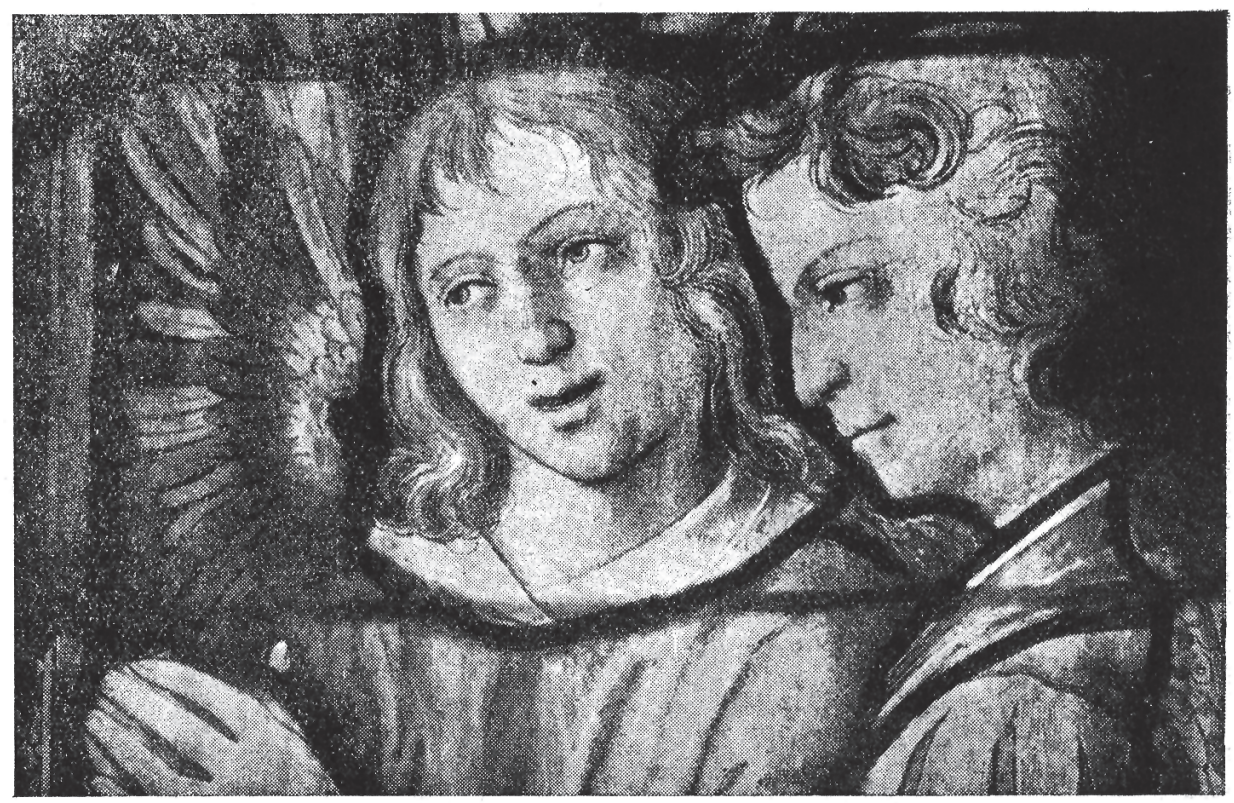

LUBECK.-IGLESIA DE SANTA MARIA

Una de las cuatrocientas magníficas vidrieras destruídas durante el ataque contra la parte vieja de lübeck en ta noche del 29 al 30 de marzo de 1942.

dos los países escandinavos, instituida hace doscientos años por un Príncipe Elector del país y dada a conocer gracias a la labor científica de los hermanos Grimm. Los archivos han sido, es cierto, menos afectados que as bibliotecas; basta, sin embargo, a estos efectos, citar la destrucción del Archivo Privado de Brandenburgo-Prusia, con numerosos documentos y papeles de Federico el Grande.

Mención especial merecen también las vidrieras policromadas medievales. Miles y miles de ventanales policromados de catedrales, monasterios, iglesias menores, museos y colecciones se hallaban a alturas de vértigo y en una situación que hacía extremada mente difícil el desmontarlos. Incluso los técnicos en este sector especial se hallaban, a veces, perplejos ante las dificultades de este trabajo. El que conocía los enormes ventanales de la catedral de Estrasburgo, con más de mil vidrieras, o los de la iglesia de Santa María, en Munich, con unas seiscientas, podrá imaginarse la complicación y dificultad que ha significado la construcción de los andamiajes gigantescos exigidos para esta labor, la selección y aprendizaje del personal auxiliar, la fotografía en negro y en colores de las vidrieros, la descripción científica de las mismas, la caracterización de cada una de ellas y el desmonte y transporte en cajas de estas obras de arte delicadísimas, a las que la exposición a todos los factores meteorológicos durante siglos habían llevado a un estado próximo a la disolución. Si los alemanes fueran esos bárbaros que dice una parte malévola del extranjero, es seguro que sería en Alemania donde menos se hubiera conservado un género artístico tan delicado y supersensible como éste. Sólo en Baviera se han desmontado las vidrieras de cien iglesias. Aprovechando el estudio directo que ha permitido esta labor, se ha llegado, por el método comparativo, a descubrir deliciosas y magistrales formas nuevas, 
las cuales habían quedado hasta ahora ignoradas, dada la altura extraordinaria a la que se hallaban las vidrieras. De esta suerte, la tarea de poner a salvo obras únicas en su género ha servido, a la vez, para enriquecer, con resultados nuevos, la historia del arte occidental.

Un primer resultado de esta labor nos llega desde Suecia. Los historiadores del arte suecos habían creído hasta ahora que la pintura de los ventanales de Suecia había nacido bajo el influjo inglés. Después de estudiar el material fotográfico obtenido durante la guerra en Alemania (la Asociación Alemana de Arte, que dirige el Dr. H. Wentzel, ha realizado más de 10.000 fotografías), los historiadores del arte sueco han llegado a la conclusión de que el estilo de una gran parte de las vidrieras suecas procede de Alemania.

Pese a las medidas de precaución tomadas en este terreno, no han podido impedirse grandes y dolorosas pérdidas, como, por ejemplo, la destrucción total, durante el ataque aéreo contra Lübeck, de todas las vidrieras -ya desmontadas y depositadas convenientemente- de la iglesia de Santa María de esta ciudad hanseática, hasta ahora tan maravillosamente conservada.

Con todos los tesoros de este maravilloso templo en ladrillo, con los leccionarios, altares y epitafios se perdió también la tabla más grandiosa del arte pictórico medieval, la célebre "Misa de San Gregorio", de Bernt Notke, pintado hacia 1504, y cuyas dimensiones eran de 2,50 × 3,50 metros. El efecto que en el ánimo causaba la vista de esta pinturatambién desmontada ya cuando fue víctima de las bombas anglosajonas-se pone de manifiesto con sólo recordar las palabras que le fueron dedicadas, hace bastantes años, por el Nuncio Pacelli, hoy Papa Pío X, con ocasión de su visita a Lübeck: "Cuán conmovedor y fructífero debió ser el espíritu revolucionario de los reformadores alemanes y cuán profundas raíces tenía que haber echado en todo el pueblo, para que surgiera una obra como ésta, de potencia emotiva y fervor religioso sin par en ningún otro país de la tierra.” (K. G. Heise, 'Die Gregormes e des Bernt Notke”, 1941; Ed. Ellermann, Hamburgo, p. III.)

Si bien todo el mundo tendrá por natural que Alemania se preocupe de la protección de sus obras de arte, es seguro que serán muchos los que no sepan que el Mando alemán ha organizado en todos los países vencidos un Servicio de protección artística, que ha seguido de cerca a las fuerzas combatientes, y cuya labor bienhechora ha merecido plácemes y altas alabanzas de parte de autoridades, funcionarios técnicos y altos dignatarios eclesiásticos de los raciones en cuestión.

Esta organización ha prestado sus servicios en Bélgica (donde ya desarrolló su actividad durante la primera guerra mundial) y Francia, en los Balcanes y, después de la traición de Badoglio, también en tierra italiana. A ella y a sus esfuerzos constantes se debe el salvamento y la conservación de muchos monumentos de valor incalculable para Europa y paro el mundo entero. ¿Qué labor tan extraordinaria la realizada por este servicio de protección artística en Francia y Bélgica!

Las obras de arte de BÉLGICA, trasladadas al Sur de Francia, fueron traídas de nuevo a su país de origen. Unos pocos ejemplos pondrán de manifiesto, asimismo, la enorme labor de protección de monumentos arquitectónicos realizada por esta organización con extraordinaria minuciosidad y sobre la base de conocimientos técnicos poco comunes. Relieves, figuras y labrados de valor en edificios sagrados o profanos han sido protegidos con revestimientos de cemento, como, por ejemplo, la entrada gótica de la capilla de la Santísima Sangre, de Brujas. La fachada del "Lepelaer”, una célebre casa de Malinas de 1519, víctima de las llamas durante el ataque aéreo aliado del 19 de abril de 1944, fue objeto de 
obras, como el relleno de los huecos de las ventanas, que evitaron su derrumbamiento; en la iglesia de Nuestra Señora de Amberes se construyó un refugio adecuado para proteger las célebres pinturas monumentales creadas para su altar por Peter Paul Rubens y sus contemporáneos; también el "Monumento al Trabajo" de Meunier, en Bruselas, fue desmontado y puesto a salvo, y el pedestal, con sus relieves, protegido por un revestimiento de cemento.

También en FRANCIA hubo que salvar y, en lo posible, restaurar los monumentos artísticos afectados por la guerra. En el verano de 1943 podía ya vanagloriarse el Servicio Alemán de Protección Artística de haber hecho posible la protección y reconstrucción de unos 300 monumentos artísticos de gran importancia. El cuidado de valiosas obras de arte y lo construcción de revestimientos y dispositivos protectores exigió también aquí un sinnúmero de esfuerzos y la movilización de todo un cuerpo de personal auxiliar y grandes cantidades de material. Nuevas dificultades ofreció también el cuidado y conservación de los castillos y palacios franceses, con su mobiliario, decoración, etc. En total había que atender en Francia a la conservación de 450 castillos y palacios. Los más valiosos entre ellos, es decir, aquéllos que guardaban un mobiliario o instalaciones de valor histórico o artístico, quedaron vedados como alojamiento para las fuerzas alemanas. De otra parte, se hizo todo lo posible para ilustrar a las fuerzas militares en este respecto, instruyéndolas por medio de visitas, conferencias, folletos, etc., sobre la importancia de los monumentos artísticos del país. A todo ello hay que añadir la necesidad de inspeccionar constantemente en sus refugios la suma de obras de arte allí transportadas, una tarea cada vez más abrumadora en los últimos años, ya que, como consecuencia de la amenaza de invasión, las obras de arte tuvieron que ser trasladadas de las regiones costeras al interior del país, y los nuevos lugares de depósito habían de ser examinados para de terminar si eran o no adecuados para ello. Este traslado, a menudo repetido, de obras de arte ha sido también el destino de bibliotecas y archivos, que después de haberse normalizado la situación en los lugares de origen eran trasladados de nuevo, para hacer posible a continuación de la labor científica. Sólo a la Biblioteca Nacional de París fueron devueltos, bajo protección alemana, 1.500 cajones, y de igual manera fueron puestos nuevamente a disposición del público los fondos de las bibliotecas de Chartres, Reims, Besançon, Le Mans, Nancy, Troyes y Versalles. La prueba más palmaria a favor de la labor realizada por el Servicio de Protección Artística alemán ha de verse en el hecho de que, a comienzos de 1943, su organización se extendió también al Sur de Francia, por haberlo pedido así insistentemente a Obra de Conservación de Monumentos francesa. De esta manera fue posible -para no citar más que algunos ejemplos-conservar el palacio de los Papas de Aviñón y toda una serie de monumentos históricamente importantes en Marsella, así como trasladar al interior del país el depósito principal de los museos nacionales franceses, establecido originariamente en Montauban.

También los monumentos de la Antigüedad y los hallazgos en suelo francés fueron objeto de cuidados especiales. Con ello, sin embargo, no terminaba la actividad del Servicio de Protección Artística, el cual, teniendo en cuenta los peligros que la guerra moderna implica para las obras de arte, ha tratado, además, de salvar y de fijar documentalmente para la ciencia todo el material que ha podido. Sólo desde el otoño de 1940 hasta el de 1941 se han realizado en la Francia entonces ocupada nada menos que 20.000 nuevas fotografías de monumentos artísticos y arquitectónicos. Miles y miles de estas fotografías son totalmente desconocidas para la ciencia francesa, ya que no se ha ahorrado esfuerzo alguno por fi- 


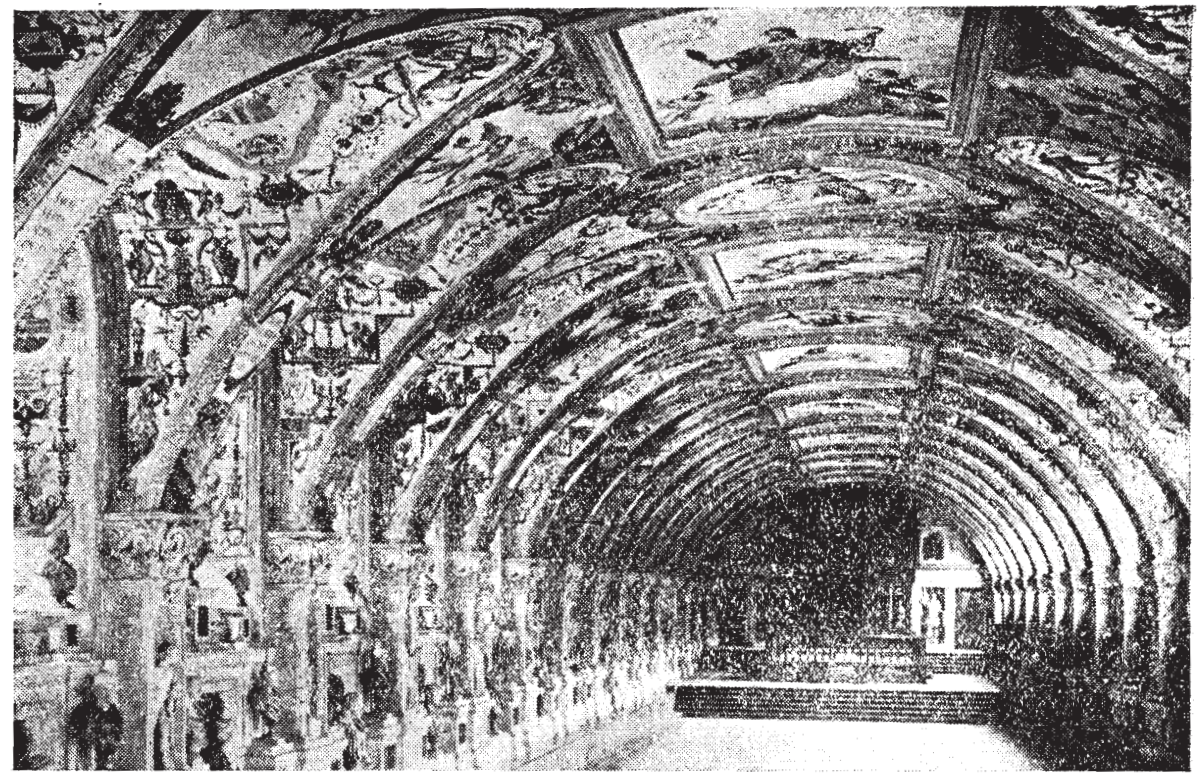

EL "ANTIQUARIUM" DE LA RESIDENCIA DE MUNICH

La más grandiosa construcción secular renacentista en sueio alemán. Construído y decorado de 1569 a 1600 para albergar la Colección Ducal de Antigüedades Clásicas.

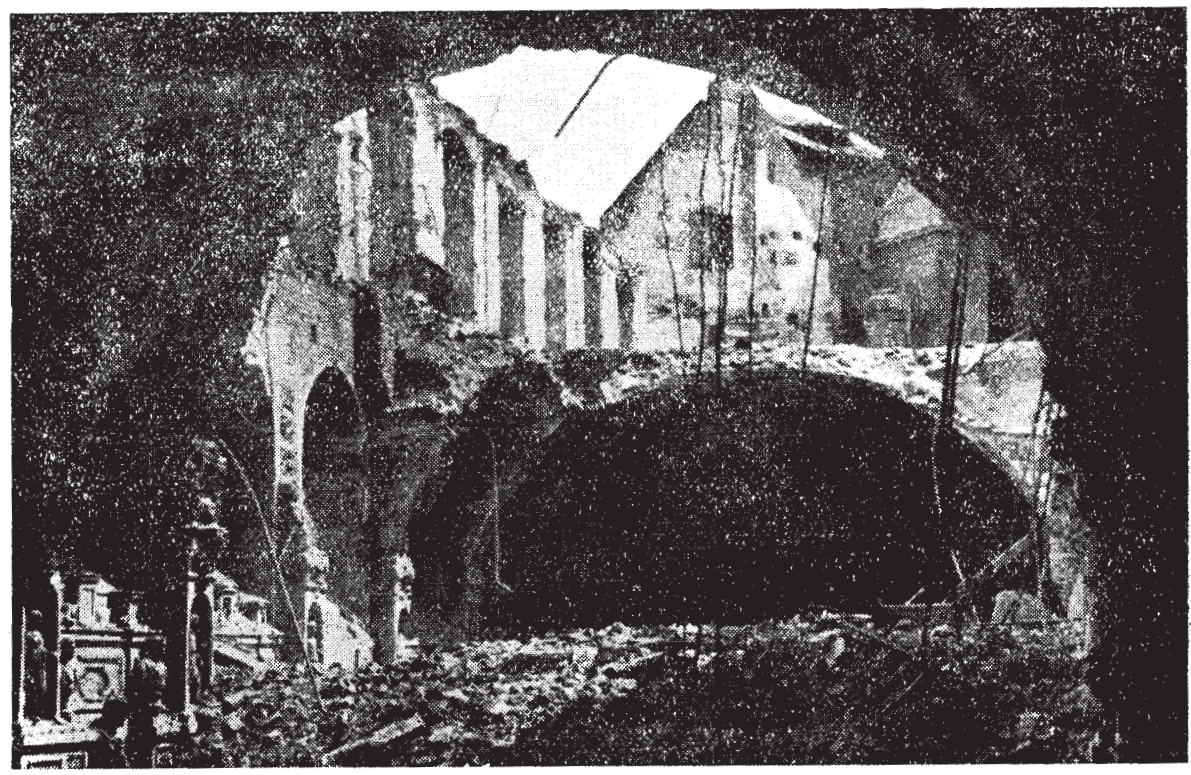

El "Antiquarium", después de los ataques aéreos del 24 de abril y del 11 de jurio de 1944. 
jar en la placa fotográfica figuras y detalles plásticos situados en lugares recónditos, a los que sólo podía llegarse con riesgo de la vida, y utilizando, a veces, los gigantescos andamiajes construidos para desmontar las vidrieros de las grandes catedrales. De esta manera se han podido descubrir obras artísticas a las que, por causa del lugar casi inaccesible en que se hallaban, no se les había prestado la atención debida o habían quedado totalmente ignoradas. El futuro mostrará las ventajas que esta labor fotográfica va a tener para la ciencia francesa.

Después de la traición de Badoglio, se organizó en ITALIA la protección artística, no sólo contra los ataques aéreos o contra la captura por fuerzas enemigas, sino también contra la acción de las partidas italianas o contra los efectos de la destrucción intencionada o casual. Esta organización tuvo lugar por el Servicio de Protección Artística afecto al Ejército alemán, en conexión con la Embajada alemana. Para comprender la situación es preciso sentar por adelantado que la protección artística italiana había sido realizada en forma muy desigual, habiéndose mostrado totalmente insuficiente después de la constitución de un frente terrestre en su propio territorio. Mucho se había hecho, sin duda, y en muchos lugares causaba una gran impresión la forma elegante e ingeniosa en que se habían construido los revestimientos protectores; pero todo ello sin duda insuficiente para hacer frente a los ataques enemigos tal y como se les esperaba en 1939, lo era aún más proteger las obras de arte de las destrucciones intensas y concentradas que, desde el año último, se hallan a la orden del día. La Organización Todt construyó, por ejemplo, muros dobles destinados a proteger de las bombas explosivas e incendiarias las maravillosas pinturas murales de Piero della Francesca en Arezzo. Como, dadas las dificultades de material y medios de transporte, no era posible neutralizar todas las deficiencias y lagunas en este terreno, el Servicio Alemán de Protección Artística procedió a proteger en su totalidad algunas ciudades de importancia singular, como Siena, Anagni y Asís, utilizándolas, a la vez, como lugares de depósito para las riquezas artísticas evacuadas de otros puntos. En la célebre ciudad medieval de Siena se ase guró el carácter de ciudad abierta y se evitó que fuera afectada por las fuerzas alemanas en sus movimientos, construyéndose a las puertas de la ciudad muros que cortaban el camino, de suerte que, aunque lo hubieran deseado, las columnas alemanas no hubieran podido atravesar la ciudad. Por orden del Führer, todas las obras de arte transportables y de valor especial de los alrededores de Roma fueron trasladadas al Vaticano, una vez comprobado que los lugares en que se encontraban no ofrecían protección suficiente. De esta manera pudieron ser puestos a seguro en los sótanos del Vaticano los ejemplares más valiosos de obras de arte de la Antigüedad, entre ellos diez cajones con plata, así como otras obras artísticas, ajuar de valor, porcelanas, labores de fundición, tapices con figuras y, muy especialmente, cuadros de los museos e iglesias de Roma, de las Galerías de Urbino, Milán y Venecia; el legendario tesoro áureo de la iglesia de San Marcos, en Venecia, y las obras de arte etrusco de Tarquinia. Poco después del transporte de las obras etruscas, fue destruido por las bombas inglesas el lugar en que hasta entonces habían estado custodiadas: el museo de Tarquinia, un maravilloso palacio de los primeros tiempos del Renacimiento. Aprovechando la ayuda de las autoridades italianas, pero, en lo esencial, gracias a la iniciativa y a la organización alemanas, pudieron así salvarse varias docenas de camiones cargados con una riqueza de valor incalculable para la cultura occidental. Por propia iniciativa, como todos supimos en su tiempo, extrajo también la División "Hermann Göring” del monasterio de Monte Cassino, sometido al fuego de los norteamericanos, el archivo de esta abadía, que es, después del archivo vaticano, el más valioso de 
todos cuantos se conservan en tierra italiana. Lo mismo hizo con depósitos de arte menor custodiados en los museos de Nápoles, y lo mismo también con los fondos de a Biblioteca Nacional de esta ciudad, que los norteamericanos, para justificar sus destrucciones, afirmaron haber sido incendiada intencionadamente por los alemanes al abandonar aquella población. Los tesoros salvados así por la División “Hermann Göring” comprendían 48 camiones totalmente cargados.

A petición del Vaticano, los alemanes prestaron también ayuda en el salvamento y transporte de archivos eclesiásticos en la zona de peligro, especialmente los de las sedes episcopales de Velletri, Gaeta, Itri, Veroli, Farentino y Anagni. También riquezas artísticas procedentes de iglesias, por ejemplo las valiosísimas de Gaeta, fue ron puestas a salvo por el Servicio Alemán de Protección Artístico.

Por lo que a las fuerzas militares se refiere, el respeto y cuidado de los monumentos y obras artísticas se hallaba garantizada tanto por prohibiciones de alojarse en edificios de valor histórico como por letreros indicadores delante de palacios, iglesias o museos importantes. Incluso tratándose de obras no transportables, situadas en puntos en los que no disponían los alemanes de la mano de obra precisa, los funcionarios del Servicio de Protección Artística se esforzaron por todos los medios en mejorar las medidas de protección adoptadas, en alejar, sobre todo, el peligro de incendio, conduciendo, por ejemplo, los fondos de archivos y bibliotecas desde los pisos altos a sótanos, a cubierto de incendio. Los diarios oficiales de viaje de los funcionarios del Servicio de Protección ofrecen indicaciones muy significativas acerca de la diversa actitud adoptada por los conservadores italianos de arte y por los altos dignatarios eclesiásticos. Muchos se mostraban agradecidos por toda la ayuda que se les prestaba e incluso trataron por todos los medios de poner a salvo los tesoros artísticos confiados a su custodia; algunos, en cambio, cerraron los oídos a las propuestas, advertencias y ayuda del personal alemán, bien porque, juzgando de la situación de entonces, no creían en la posibilidad de un peligro próximo, bien porque sentían con ello disminuida su autoridad. Al descargar la guerra sobre ellos, como consecuencia de nuestros movimientos de repliegue o en virtud de bombardeos aéreos concentrados, es seguro que se habrán percatado cruelmente de la negligencia de que se han hecho culpables.

Si ya una orden expresa del Führer había prohibido a las fuerzas alemanas cañonear o bombardear en el curso de acciones bélicas la capital de GRECIA, con todos sus monumentos milenarios, hoy que considerar, además, como mérito glorioso del sentido cultural del Ejército del Reich, que en tierra firme griega no ha habido que lamentar ningún daño en obras artísticos que haya sido debido a acciones militares de parte de los soldados alemanes. En algunas islas se han producido daños por los bombardeos, pero sólo en construcciones de valor secundario que, además, se hallaban totalmente abandonadas por la Administración griega.

Por lo que a los aliados se refiere, fuerzas inglesas fueron las que, en Creta, destrozaron, corno si se tratase de cacharros viejos, el contenido de la casa en que reunía el resultado de sus excavaciones el célebre arqueólogo inglés Sir Arthur Evans, el excavador de Knossos; y fuerzas inglesas fueron, asimismo, las que arrojaron al patio el contenido del Museo de Chania, en Creta; las que bombardearon repetidamente el santuario de Ceres en Eleusis y el palacio veneciano de Corfú, donde se hallaba instalado un museo. Barcos de guerra ingleses fueron también los que cañonearon en Rhodas las construcciones medievales de lo Orden de los Caballeros de San Juan.

Pese a todo, los daños causados por la evacuación apresurada e improvisada de obras 
de arte realizada par el Gobierno griego a comienzos de la guerra superan con mucho todos los daños y pérdidas sufridos como consecuencia de acciones militares. No es extraño, par todo ello, que la primera medida en Grecia del Servicio Alemán de Protección Artística tuviera que ser una reforma profunda de la labor realizada por a Junta Griega de Conservación de Monumentos. De quince Delegaciones Provinciales que integraban ésta no se hallaban provistas más que seis, y éstas en forma insuficiente. Trabajos tan urgentes coma los destinados a la conservación de los antiguos muros del puerto del Pireo o del palacio real de Micenas estaban aún sin empezar. La inspección por parte del Estado había fracasado en tales proporciones, que en el distrito de Laurion, por ejemplo, en la costa oriental del Ática, desaparecieron durante los últimos treinta años cuatro quintas partes de las inscripciones antiguas. Las pérdidas por excavaciones clandestinas, robos, etc., superaban con mucho en un solo año de paz todas las pérdidas que han sido causadas por la guerra. El Servicio Alemán de Protección Artística tenía, por eso, que reformar en primer lugar toda la labor de la Junta de Conservación de Monumentos. Gracias a los esfuerzos constantes del Servicio Alemán se logró que el número de los conservadores provinciales fuera elevado de quince a veintisiete y que todas las plazas fueran provistas. Para el cuidado de las antigüedades bizantinas, de las que desde hacía veinte años nadie se había preocupado, se crearon cinco Delegaciones, y las catorce existentes para las antigüedades de la época clásica fueron elevadas a veintitrés. Al Servicio Alemán de Protección Artística hay que agradecer que se realizaran obras de protección en las murallas de la península del Pireo (siglo VI antes de Cristo), en el santuario de Poseidón en el cabo Sunión (siglo V a. d. C.), en el castillo de Tirinto (II milenio a. d. C.), en el santuario de Samos (siglo VI a. d. C.), en el suelo de mosaicos de Nicópolis ( siglo VI a.d. C.) y en otros muchos lugares.

La instrucción e ilustración de las fuerzas alemanas por medio de las "Hojas ilustrativa para el soldado alemán destacado en los lugares históricos de Grecia”, repartidas en centenares de miles de ejemplares, muestran que tampoco por este lado se quedó nada por hacer.

La Junta Griega de Conservación de Monumentos fue constantemente apoyada, haciéndose efectivamente posible su labor con suministros de materias primas, como, por ejemplo, con la entrega de bronce procedente de presas marítimas, el cual pudo utilizarse para la construcción de grapas destinadas a mantener unidos los sillares de los monumentos clásicos de la Acrópolis; mientras que el hierro que antes se empleaba para este menester hacía saltar la piedra y ponía, por tanto, en peligro la subsistencia de las más grandiosas obras artísticas de la Antigüedad.

La atención dedicada a los museos alcanzó tales proporciones, que, desde 1941, el Servicio Alemán de Protección Artística reformó y estableció como museo en Chania una mezquita abandonada. No hace falta subrayar, por evidente, que este Servicio fomentó también investigaciones científicas, especialmente excavaciones; así, por ejemplo, en Olimpia y Creta, los resultados de las cuales serán publicados por el Instituto Arqueológico del Reich. La protección se extendió incluso a los trabajos del Instituto Arqueológico francés.

Todos los hallazgos hechos por as fuerzas alemanas en el curso de trabajos en el terreno - de los cuales el más importante fue una estatua de mármol encontrada en Salónicafueron entregados a los museos griegos.

El Servicio Alemán de Protección Artística, cuya labor en SERVIA comenzó después de la campaña balcánica de 1941, se vio aquí ante el dificilísimo cometido de organizar. Una Junta de Conservación de Monumentos, que hasta entonces faltaba en el país, y de ini- 


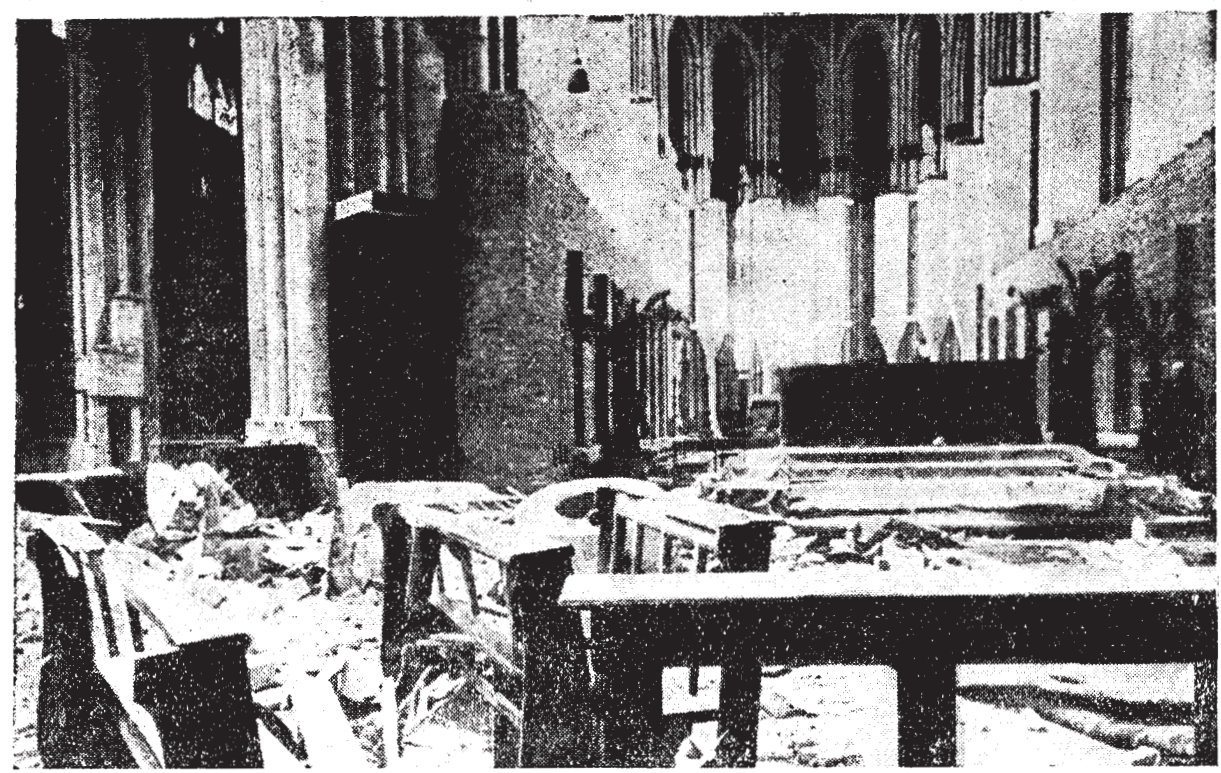

COIONIA.-INTERIOR DE LA CATEDRAL

Revestimiento de la sillería del coro y de las estatuas en las columnatas.

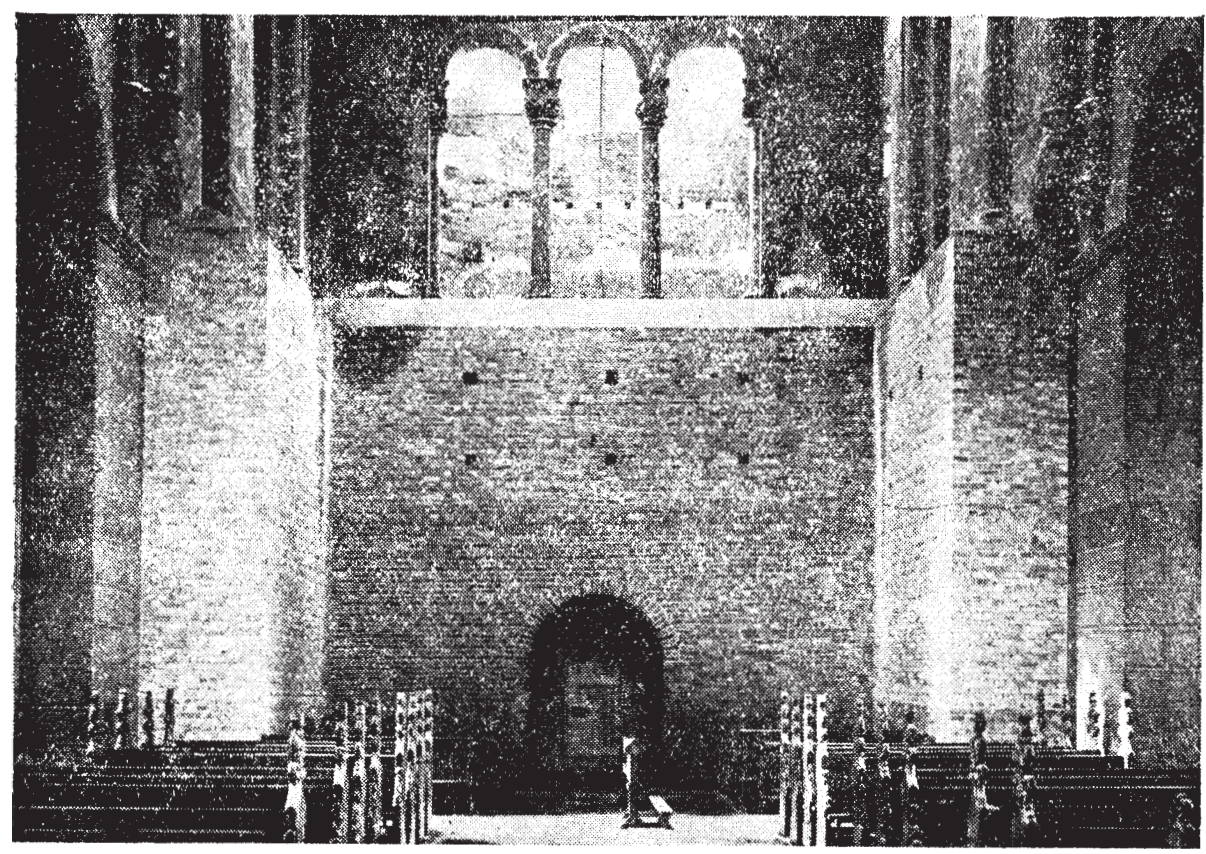

Revestimiento del leccionario de la iglesia de Santa María en el Capitol, de Colonia. 
ciar un inventario general de los monumentos y obras artísticas servias. Esta labor era condición previa indispensable para dar comienzo a la protección de los monumentos muebles e inmuebles. Había que ordenar y, a medida que se agudizaba la situación bélica, que evacuar los museos, que preservar de daños a centenares de monasterios, iglesias y castillos históricos; había, en fin, que proteger o, al menos, que inventariar y evacuar los hallazgos de numerosos lugares prehistóricos, romanos y primitivos, poniéndolos a cubierto de las consecuencias de acciones bélicas, construcción de fortificaciones, edificios, etc. Como resultado de la labor en el sector de los museos, mencionemos tan sólo la Exposición Étnico Balcánica celebrada en el Museo Étnico de Belgrado, en la cual se ofreció por primera vez una visión de conjunto sobre la cultura de a zona montañosa de los Balcanes occidentales, es decir, de la llamada "zona patriarcal”, una región cultural cuyo carácter autóctono e incontaminado la hace única en Europa, y que ofrece material insospechado para la etnografía comparada europea.

El fichero sobre Servia del Servicio Alemán de Protección Artística abarca unas 800 iglesias, 300 castillos y más de 1.000 lugares en los que se han encontrado restos prehistóricos y primitivos, algunos de ellos de una significación que, al decir de los entendidos en la materia, nada tiene que envidiar a la de Troya. Muchos de los monumentos inventariados han sido posteriormente víctima de os repetidos ataques aéreos aliados contra Belgrado y una serie de otras ciudades y villas servias, o han desaparecido bajo el terror de las partidas. El trabajo de ordenación e investigación con-tenido en el fichero alemán reviste, por ello, un valor histórico del que no podrá prescindir en el futuro a ciencia que se ocupe de arte del pueblo servio.

El Servicio de Protección Artística afecto a la Administración militar alemana en Servia ha mostrado una objetividad en la elección, dirección y fomento del personal auxiliar del país, así como uno reserva por parte de los delegados alemanes, que sólo encontrará el debido reconocimiento cuando, en un futuro de paz, se haya conseguido la superación de todo lo que hoy separa a los pueblos.

Este breve resumen sobre la labor del Servicio Alemán de Protección Artística, dependiente de los comandantes en jefe de las fuerzas alemanas de ocupación en los diversos países europeos, descansa sobre la base de documentos irrefutables y declaraciones auténticas de representantes autorizados de los países en cuestión, así como sobre documentos y fotografías de procedencia alemana. 'Mediante este material probatorio quedaron desvirtuadas a su debido tiempo los especies difamatorias difundidas por l propagando anglosajona, de creer a las cuales los alemanes habrían constituido compañías expoliadoras" dedicadas afanosamente al robo de tesoros artísticos en los países ocupados, llegándose a precisar que la "Victoria de Samotracia" del Louvre se hallaba en el despacho del Führer en Berlín y la "Venus de Milo", en la residencio del Mariscal del Reich Góring, para no hablar de lo Mona Lisa”, de Leonardo de Vinci.

Con serena actitud puede Alemania pasar por alto toda esta serie de infundios viles. Hasta qué punto la parte contraria podré dar cuenta un día de la desaparición de las joyas de lo corona de los Staufer, custodiadas en el tesoro catedralicio de Palermo; de la destrucción intencionada de edificios y figuras procedentes de la Antigüedad clásica y de la Edad Media, y de la desaparición de pinturas y estatuas celebérrimas, es algo que queda todavía por ver.

La misma cosa realizada por dos personas reviste, a veces, aspectos muy diferentes, Los calumniados alemanes han fotografiada con todo detalle y estudiado, por medio de su Ser- 


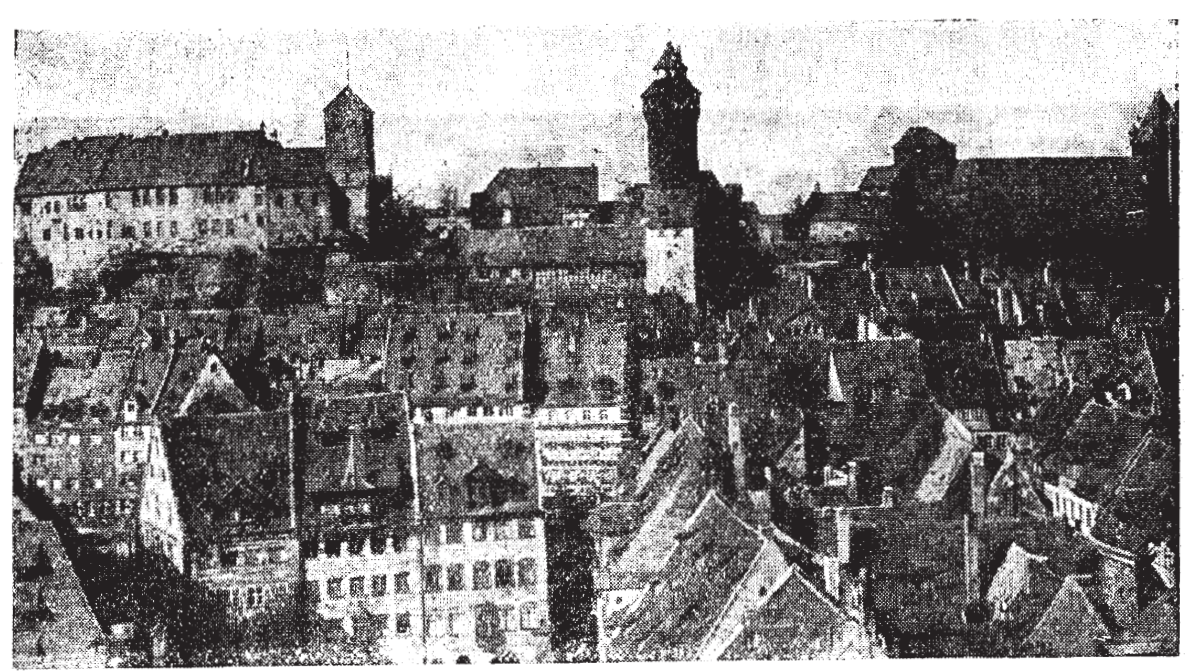

\section{NUREMBERG}

Vista panorámica de la parte vieja de Nuremberg en 1939. "iNuremberg! ITú, un día famosa en el mundo entero! i Con qué placer recorro tus callejas retorcidas, con qué amor infantil contemplo tus patriarcalés casas y tus iglesias, en las que se halla impresa la huella firme de nuestro antiguo arte patrio!" (Wackenroder, "Phantasien über die Kunst", 1797.)

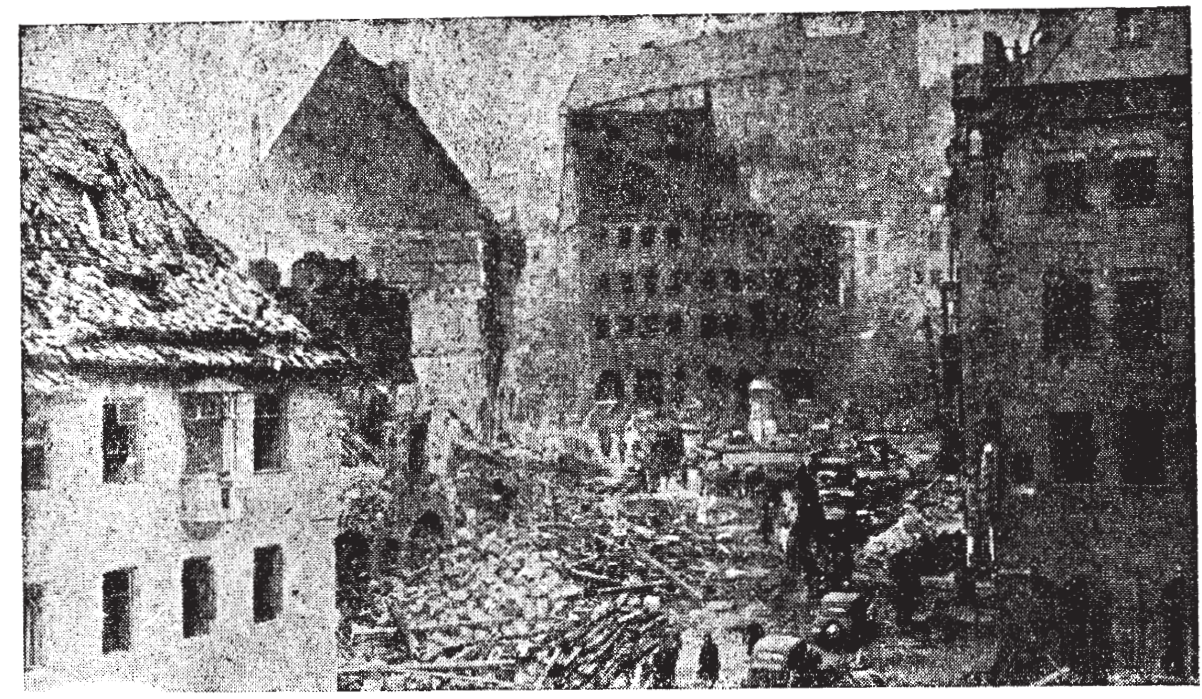

\section{NUREMBERG}

La plaza de Alberto Durero, y a la derecha, en primer plano, las ruinas de la capilla de San Mauricio y del celebérrimo Bratwurstgióckleins. A la izquierda, en primer plano, ic rectoral de San Sebaldo, destruída en su parte posterior. En medio de la plaza, el monumento a Durero de Rauch. Estado después de un ataque te. rrorista en el otoño de 1944. 
vicio de Protección Artística en Francia, la estructura material y las características del tapiz de Bayeux, célebre obra de arte de 70 metros de largo, representando la conquista de Inglaterra por los normandos en 1066. A los norteamericanos les estaba reservado Llevarse esta obra única, en cuanto pusieron el pie en el continente.

El comportamiento del Servicio Alemán de Protección Artística en los diferentes países prueba que, en el fondo, no se atenía en su labor a una fórmula burocrática estricta, sino que sabía adaptarse con flexibilidad a los situaciones y exigencias locales, siempre guiado por una divisa: ¿Qué puedo hacer que redunde en beneficio de las obras de arte? Allí donde a conservación de monumentos se hallaba altamente desarrollada, corno en Francia, la labor a realizar era muy otra que, por ejemplo, en los países balcánicos. La negligencia reinante en territorio griego forzaba a procedimientos totalmente diversos que en Servia, donde puede decirse que todo se hallaba por hacer.

De las expoliaciones artísticas del Estado napoleónico, cuya injusticia aún en pie hemos cancelado al recuperar las armas y estandartes probadamente robados, hasta la rapiña artística de los norteamericanos, va un camino directo, en el cual se ha cruzado, como excepción señera, a conducta de Alemania en esta guerra. Por primera vez en la historia de la guerra, un pueblo que se halla en guerra con otro ha procedido a custodiar cuidadosamente los valores y monumentos culturales de este último, defendiéndolos a menudo incluso contra la negligencia o los intentos de destrucción por parte de la misma nación a la que pertenecían.

Los alemanes estiman las obras maestras de la cultura, hállense donde se hallen y procedan de quien procedan, independientemente de las rivalidades y parcialidades de la guerra. Para Alemania, estas obras son exponentes y testigos venerables de los más alto anhelos de la Humanidad.

¿Qué país puede presentar una suma tal de ciudades con fisonomía propia como Alemania? Lo mismo si se hallan situadas al pie de las montañas que si se encuentran en las altiplanicies, al margen de bosques y carreteras o a orillas de ríos o lagos, se vean o no coronadas por castillos, palacios, catedrales o torras, las ciudades alemanas poseen siempre un carácter propio e inconfundible. Es conocida la significación de la vida municipal alemana para e desarrollo de la cultura occidental. Cuando el Derecho municipal de Magdeburgo se disponía a ejercer su benefactora misión en el Este de nuestro continente, se levantó a catedral de la ciudad, que ha quedado incólume hasta nuestros días, a través incluso de los incendios y matanzas de la Guerra de los Treinta Años. Tenían que venir los bombarderos anglosajones de esta guerra para que este templo venerable sufriera graves daños. Sea cual sea el sector de la historia municipal que estudiemos, por doquiera se ve actuando determinantemente el sentido planificador, activo e ingenioso de os alemanes. $Y$ de valor es no sólo lo que estas ciudades significaron en un tiempo o qué personalidades nacieron de su ambiente, sino también lo que han llegado a ser hasta nuestros días, en un proceso continúo de crecimiento orgánico, y lo que, por tanto, han significado para la formación de todo hombre con sentido cultural.

Evóquese sólo el recuerdo de la multitud de ciudades alemanas incomparables en su belleza, como, por ejemplo, el encanto de a viejo Innsbruck, rodeada de montañas, o el Callejón de los Caballeros, en Viena, con sus grandiosos palacios encerrando múltiples patios en su interior, o las maravillosas Casas Consistoriales de Elías Hall, en Augsburgo, con la celebérrima Sala Áurea, que tantas solemnidades oficiales ha presenciado entre sus paredes en el curso de los siglos, o la Factoría de los Fúcar, también en Augsburgo, la barriada 
social más antigua en Europa, considerada hasta los últimos tiempos como un modelo en la disposición y en su eficacia; o piénsese en la cadena de barrios de casas típicas, desde Francfort hasta Kassel, y desde Hannover a Brunsviga e Hildesheim, y en las fachadas de ladrillo bajoalemanas, unas enfrente de otros, tal como se mostraban al visitante en forma única en Rostock, Emden, Bremen o en Lübeck, la antigua y célebre ciudad hanseática. Doquiera dirigiéramos los pasos en Colonia, la ciudad sagrada, favorita del arte y riquísima en iglesias, toda una multitud de recuerdos que se remontaban a la época romana surgía ante nuestros ojos. ¿Qué ha quedado de todas estas ciudades? ¿Qué resto de 'la vieja Colonia, con su panorama cuajado de torres como en el siglo XVI, que fue, hasta esta guerra, la delicia de todo viajero del Rhin? ¿Qué heridas no causó o Tréveris tan sólo el bombardeo del 14 de agosto de este año, ocasionando daños graves a su catedral, el templo más antiguo de Alemania, así como a la iglesia de Santa María, reduciendo a cenizas la antiquísima basílica, incendiando el Palacio de los Príncipes Electores, haciendo desaparecer entre las llamas el palacio Kesselstadt, tan magníficamente instalado, y numerosas casas góticas y barrocas! ¿No era conocida la catedral de Aquisgrán, lo mismo que Tréveris, hasta en los últimos rincones de Europa, gracias a una corriente de peregrinos que no ha cesado de acudir a la ciudad en los últimos cuatrocientos años? Y, sin embargo, tampoco la catedral de Aquisgrán ha sido respetada. ¿Qué ha quedado en pie de la Sala de los Emperadores en las Casas 'Consistoriales de Aquisgrán, embellecida por las pinturas murales de Rethel? ¿Qué de la Couvenhaus, a magnífica e intacta construcción del rococó, que, como museo vivo, ponía de manifiesto el sentido para la belleza de aquella época y que movía, incluso a turistas ingleses, a prorrumpir en himnos de alabanza ante tanta magnificencia? En el libro de visitantes de este monumento único podían leerse, por ejemplo, palabras como éstas: "Vengo desde el Extremo Oriente para contemplar esta maravilla." Y así puede recorrerse el Rhin aguas arriba y aguas abajo, visitar Karlsruhe con sus iglesias y palacios, Mannheim, Maguncia, Düsseldorf, y por doquiera se hallaron ruinas y más ruinas hasta donde la vista alcanza. Incluso villa tan pequeño como Neuss ha perdido su misma esencia con la destrucci6n de lo iglesia Quirina, cuyo desaparición ha significado la pérdida de una joya de valor incalculable para toda la región. En Hannover ha sido destruida la casa de Leibnitz, rico y magnífico edificio renacentista, que se destacaba dentro de calles formadas por casas típicas con el mismo señorío y predominio con que el más relevante de todos sus habitantes, el filósofo Leibnitz, sobresaliera un día entre las más ilustres personalidades de su siglo. Con este edificio, único, ha desaparecido en Hannover todo el centro de la ciudad, así como las residencias allí y en Herrenhausen, repletas de recuerdos de reyes ingleses, oriundos de estas ciudades. Junto a las destrucciones perpetradas en ellas se alzan también pequeñas ciudades apartadas, tal como Tübinga y Marburgo, las dos ensoñadoras villas universitarias, antes escogidas por los hombres de ciencia del mundo entero para dedicarse en ellas a lo paz de los estudios; residencias de soberanos y lugares de peregrinación, a la vez, para todos los amantes del arte, como Schwerin, Dormstadt, Weimar o Dresde, y antiquísimos puntos de confluencia cultural, como Hildesheim o Erfurt. Con motivo del terremoto de Lisboa, los contemporáneos se sintieran estremecidos de espanto, y, sin embargo, esta catástrofe del siglo XVIII no revistió más que proporciones mínimas en comparación con lo que representa este bombardeo continuado de Europa.

¿No se dan cuenta los responsables de estos ataques aéreos que con tales destrucciones se extingue un fenómeno cultural que desaparece ya irrecuperablemente? Esta furia destructora ha hecho desvanecerse la atmósfera de estas ciudades, una atmósfera que se 
corporeizaba hasta en el dialecto de los habitantes de las diversas partes de la población, en el estilo de las viviendas y en las costumbres, en los usos y en las formas de vida.

Cuando, hace unos años, fue arrasada la parte más bella de la vieja Lübeck, entre la iglesia de Santa María y la catedral, se hallaban en pie, intactas, las mayores fábricas de armamento alemanas. Cuando el fósforo de las bombas aliadas aniquiló la parte vieja de Kassel, exterminando con ella numerosas familias que allí vivían, ninguna instalación industrial de importancia militar se hallaba en las proximidades de los lugares destruidos. No obstante, los neutrales e incluso muchos habitantes de las ciudades todavía no atacadas siguieron creyendo que sólo podía tratarse de un error tremendo. Ni los unos ni los otros so atrevían a creer que se trataba de un plan organizado, frío y despiadado. En Nuremberg fueron dañados varias veces el castillo y la casa de Durero, y alcanzados los almacenes góticos, las deliciosas murallas en torno a lo ciudad y toda una serie de antiguos torreones. ¿Qué queda de las residencias eclesiásticas en Münster, de lo belleza de su catedral y de tantas iglesias? ¿Qué de Munich, la ciudad del arte, tal como la creó Luís I, cuya misma tumba ha sido también profanada? ¿Quién se atreve a reconocer la vieja Estrasburgo, después de que ya en el primer ataque fueron alcanzadas [a catedral, símbolo de Occidente; la Frauenhaus y el palacio de Rohan, siendo reducido a cenizas la casa de comercio gótico a orillas del Yll y demolidas la plaza de Gutenberg y sus inmediaciones?

Al ver cómo un Mariscal del Aire norteamericano lanza sus “tapices de bombas' sin preocuparse de las más sublimes bellezas encerradas en las ciudades de Europa, que no son para él, según sus mismas palabras, más que "baratijas para tarjetas postales", nos viene a la memoria la perspectiva a ras de tierra, desde la que los norteamericanos de antes de la guerra solían contemplar en manada nuestros lugares más venerados. Una vez pude verlos recorriendo a paso gimnástico la gran galería del Louvre, deteniéndose, por indicación del guía, ante el Leonardo da Vinci más recomendado por el Baedeker, contemplándolo de arriba abajo un momento, mientras sus mandíbulas mascaban el "chiclet" de rigor. Los he visto también en Chartres bajar del autocar y precipitarse por la catedral hacia la torre, y los he visto atravesar a toda velocidad, con sus grandes automóviles, ese idilio en piedra que es Orvieto. Sólo ante el célebre globo terrestre de Martín Behaim (1492), en el Museo Nacional Germánico de Nuremberg, se detenían un momento, y aquí tan sólo porque el gran geógrafo nada supo de su existencia, porque - iqué tiempos tan dichosos!_-todavía no se hallaba reseñada América en los mapas más importantes de la época.

Durante un viaje de estudios por los Estados Unidos, hace unos quince años, un compañero mío echó de ver, en la colección de arte de un rico norteamericano, que una antigua pintura de valor se hallaba casi tapada por un aparatoso armario colocado delante de ella. Preguntado por la razón de ello, el propietario le dijo: "El cuadro se halla reproducido en los libros que tratan de la materia, donde todo el mundo puede contemplarlo. Basta, pues, que se vea de él lo suficiente para saber que yo lo poseo, y, además, el armario me ha costado más dólares que la pintura”.

He aquí la forma más tosca y desespiritualizada de posesión de obras de arte; posesión entendida como pedestal para la arrogante vanidad de sus sedicentes propietarios. Aquí no hay posesión espiritual, ni esa voluntad de apropiación de la obra artística transmitida entre nosotros de generación en generación como una necesidad intima, de acuerdo con el imperativo goethiano: Adquiere aquello que has heredado de tus padres, para poseerlo así verdaderamente. 
Algo infranqueable nos separa en este punto. Entre nosotros, el más pobre es, sin embargo, rico por la reelaboración espiritual del legado cultural que nos ha sido transmitido; reelaboración por lo que se convierte en verdadero poseedor de aquellos valores imperecederos que, como la más noble herencia, defendemos con fiero fanatismo. Sólo un corazón europeo podía dictar las palabras que en 1800, escribía Carolina a August Wilhelm Schlegel: "Repítete incesantemente, querido amigo, cuan breve es la vida y que nada existe tan verdaderamente como una obra artística. La crítica desaparece, estirpes y generaciones se extinguen y los sistemas políticos cambian; pero si el mundo ardiera una vez como un trozo de papel, las obras de arte serían los últimos destellos que llegarían al trono del Señor. Entonces, en efecto, sólo entonces, vendrían las tinieblas”. 